\title{
Sulphur isotopes in anhydrite from Badenian (Middle Miocene) salts of the Hrynivka area (Ukrainian Carpathian Foredeep)
}

\author{
Anatoliy R. GALAMAY ${ }^{1}$, Fanwei MENG ${ }^{2}$ and Krzysztof BUKOWSKI $I^{3, *}$ \\ 1 National Academy of Sciences of Ukraine, Institute of Geology and Geochemistry of Combustible Minerals, Naukowa 3A, \\ 79060 Lviv, Ukraine \\ 2 State Key Laboratory of Paleobiology and Stratigraphy, Nanjing Institute of Geology and Paleontology, Chinese Academy \\ of Sciences, Nanjing 210008, China \\ 3 AGH University of Science and Technology, Faculty of Geology, Geophysics and Environment Protection, \\ Al. A. Mickiewicza 30, 30-059 Kraków, Poland
}

Galamay, A.R., Meng, F., Bukowski, K., 2014. Sulphur isotopes in anhydrite from Badenian (Middle Miocene) salts of the Hrynivka area (Ukrainian Carpathian Foredeep). Geological Quarterly, 58 (3): 439-448, doi: 10.7306/gq.1159

Ten new determinations of the stable sulphur isotope content of anhydrite from Badenian rock salt in the Hrynivka 525 borehole (Ukrainian Carpathian Foredeep) show that $\delta^{34} S$ values in anhydrite range from +20.2 to $+22.7 \%$ and the average value of $\delta^{34} \mathrm{~S}$ is $+21.4 \pm 0.3 \%$. Those values are similar to those of the Neogene marine sulphates. Comparison to other geochemical data (chemical composition of the brine contained in fluid inclusions and the bromine content in halite) suggests that the Badenian Carpathian Foredeep evaporite basin was supplied predominately by sea water solutes where, at different stages of salt accumulation, the influence of continental waters with lighter isotopic compositions of dissolved sulphate was important. The isotopic composition of sulphur $\left(\delta^{34} S\right)$ of Badenian seawater, calculated on the basis of sixty analyses of anhydrite related to halite of the Carpathian region, is approximately $+20.3 \%$, this value being similar to the sulphur isotopic composition of present-day seawater. The $\delta^{34} S$ value for Badenian sea water may have been slightly higher if we consider potential changes of the brine composition of salt-bearing basins caused by inflow of continental waters enriched in light ${ }^{32} \mathrm{~S}$ isotopes.

Key words: anhydrite, sulphur isotopes, rock salt, Badenian, Miocene, Carpathian region.

\section{INTRODUCTION}

The isotopic signal of stable sulphur isotopes in anhydrite is an important indicator of the origin and the depositional environment of evaporites. Isotopic composition studies are helpful in the interpretation of the physical and chemical conditions of sulphate crystallisation, diagenetic evolution, and subsequent transformation in sulphate reduction and the oxygenation cycle (e.g., Lloyd, 1968; Longinelli, 1979; Pierre, 1985; García-Veigas et al., 2011).

The sulphur isotope content of anhydrite, co-occurring with salt deposits, is an important source of information about the origin of salt and the contribution of dissolution and recrystallisation processes of earlier evaporite formations (recycling; Nielsen, 1972). The determination of stable sulphur isotopes $\delta^{34} S$ in the anhydrite originating from the Badenian salt succession of the Carpathian area has been the topic of previous research (e.g., Claypool et al., 1980; Galamay, 1997; Bukowski and Szaran, 1997; Parafiniuk and Hałas, 1997; Peryt et al., 1997,

\footnotetext{
* Corresponding author: e-mail: buk@agh.edu.pl
}

Received: April 29, 2013; accepted: January 10, 2014; first published online: March 25, 2014
1998, 2002; Cendón et al., 2004; Kasprzyk and Bukowski, 2009; Jasionowski and Peryt, 2010).

In the present study, the results of new $\delta^{34} S$ determinations are provided for anhydrite from the salt-bearing deposits of the Hrynivka area (the central part of the Ukrainian Carpathian Foredeep; Fig. 1). This research was carried out on the same samples of rock salt that have previously been used for analyses of fluid inclusions (Galamay, 2010), bromine content (Galamay, 2003) and strontium isotopes (Peryt et al., 2010). The aim of our study was to identify a correlation between the sulphur isotopic composition of the Hrynivka anhydrite and other regional geochemical data. In our discussion of the results, we compare the determination of the stable sulphur isotope content $\left(\delta^{34} S\right)$ in the Hrynivka anhydrite with the isotopic composition $\left(\delta^{34} S\right)$ of anhydrite originating from other parts of the Badenian basin of the Central Paratethys in the Carpathian region (Fig. 1). Our results are compared to the isotopic composition of dissolved sulphate originating from modern seawaters.

\section{GEOLOGICAL SETTING}

The Carpathian Foredeep Basin was formed north-east of the overthrust Carpathian nappes in the Early Miocene. It is filled with Miocene deposits, more than 3000-m-thick, in the 


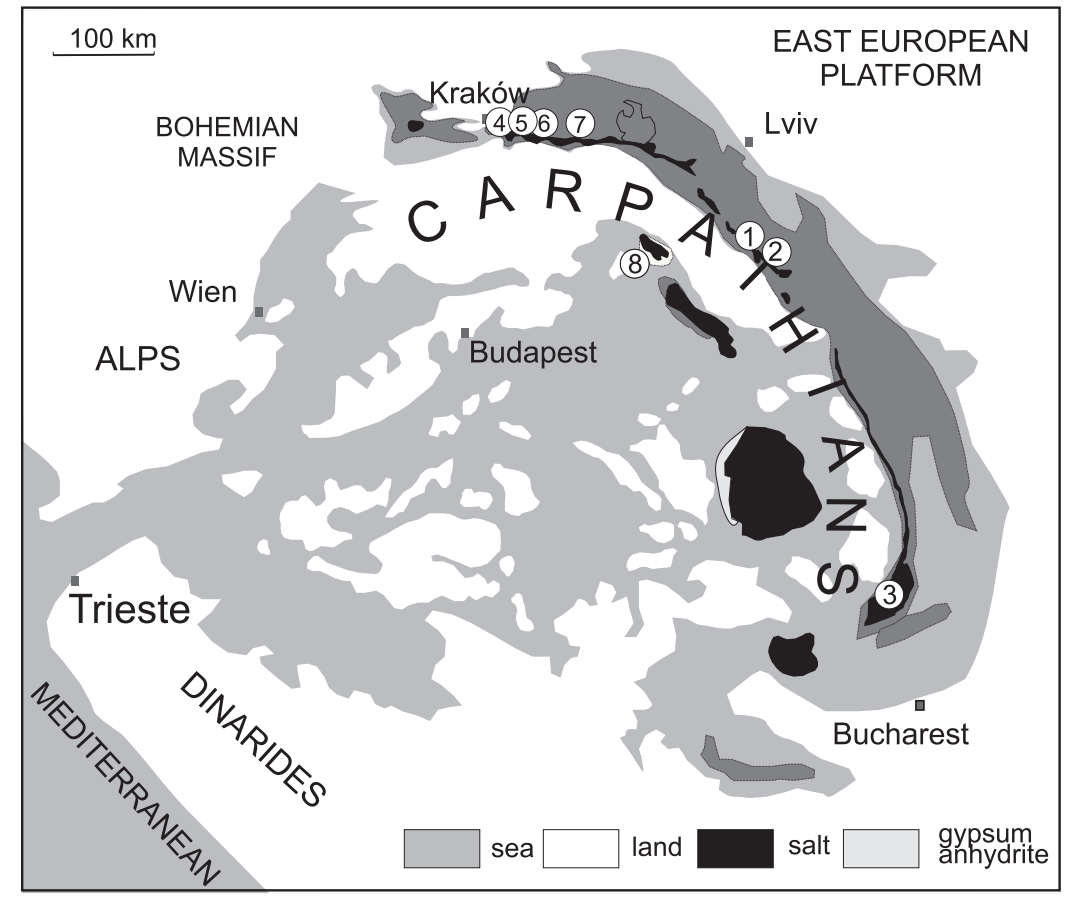

Fig. 1. Palaeogeographic map of the Badenian salt-bearing basins in the Carpathian region (after Bukowski et al., 2007) with an indication of salt deposits that were analysed for $\delta^{34} S$ in anhydrite

Salt deposits: 1 - Hrynivka, 2 - Zabolotiv, 3 - Slanic-Prahova, 4 - Barycz, 5 - Wieliczka, 6 - Bochnia, 7 - Wojnicz, 8 - Zbudza

area adjacent to the Carpathians. In the Ukrainian part of the Carpathian Foredeep, three tectonic zones are distinguished: outer (Bilche-Volytsia), central (Sambir Nappe thrust over the foreland), and inner (Boryslav-Pokuttya Nappe) thrust over the Sambir Nappe and the underlying foreland (Vul et al., 1989; Oszczypko et al., 2006).

The Badenian evaporites occur in the Bilche-Volytsia Zone, as well as locally on the Sambir Zone (e.g., in the areas of Drohobych, Hrynivka, and Lopushna). Those evaporites (sulphate-carbonate, and sulphate and rock salt) belonging to the Tyras Suite (Formation) are correlated with the Wieliczka Formation in the Polish part of the Carpathian Foredeep (Andreyeva-Grigorovich et al., 2003), as well as other salt formations in Romania and Slovakia (Khrushchov, 1980). The evaporites of the Tyras Suite overlie the deposits of the Bohorodchany Suite, occurring in the central Sambir Zone of the Carpathian Foredeep, or the Baraniv beds in the Bilche-Volytsia Zone (Peryt, 2006) and other older deposits (Stupnitskiy et al., 1978), and are overlain by the laminated clays and siltstones of the Kosiv Suite deposits (Korenevskii et al., 1977; Khrushchov, 1980) and locally by the Ratyn Limestone (Peryt et al., 2012 with references therein).

Thirteen boreholes were drilled during exploration for potash salts in the frontal part of the Sambir Zone in the Hrynivka area (ca. $12 \mathrm{~km}$ SE of Kalush) in 1975-1978 (Fig. 2). Our studies involved the samples collected from the Hrynivka 525 borehole located in the NW part of the area.

\section{MATERIALS AND METHODS}

Rock salts were drilled to depth of $272 \mathrm{~m}$ in the Hrynivka 525 borehole. The lower part of the salt succession was not reached due to drilling rig malfunction at $541 \mathrm{~m}$. In total, 22 samples were collected for laboratory tests of which new determinations of stable sulphur isotope content were carried out on ten samples. The anhydrite collected for tests occurred in the form of white-blue nodules (of diameter $1-10 \mathrm{~mm}$ ) found on the boundaries of coarse crystalline halite and claystone (Fig. 3). Only one sample (no. 1350) came from massive anhydrite in the rock salt.

The determinations of the isotopic composition of sulphur in the anhydrite of the Hrynivka salt succession were performed in the Institute of Geology and Geophysics, Chinese Academy of Sciences (IGGCAS), using a Finnigan Delta $S$ gas source mass spectrometer. The sulphur isotope analysis method was modified with respect to that of Halas and Szaran (1999). Approximately $15 \mathrm{mg}$ of $\mathrm{CaSO}_{4}$ was mixed with $\mathrm{NaPO}_{3}(150 \mathrm{mg})$ and combusted in the presence of copper turnings (150 mg) under vacuum, for conversion to sulphur dioxide at $750^{\circ} \mathrm{C}$, for 15 minutes. Sulphur isotope results (V-CDT, Vienna-Canyon Diablo Troilite) are generally reproducible within $\pm 0.3 \%$.

In this study, we also summarize previously published determinations of the $\delta^{34} S$ values of anhydrite originating from various parts of the Badenian salt basin. Those studies were mostly conducted with the use of a three-collector mass spectrometer, with a two-channel dosing system, at the Laboratory of the Institute of Physics of the Maria Curie-Skłodowska University in Lublin, Poland. The method was described in detail by Halas and Szaran (1999). The values of $\delta^{34} \mathrm{~S}$, obtained with an accuracy of $\pm 0.05 \%$, represented a relative difference in \%o between the isotope proportions $\left({ }^{34} \mathrm{~S} /{ }^{32} \mathrm{~S}\right)$ of the sample and those of the standard V-CDT.

\section{RESULTS}

Considerable quantities of anhydrite nests and overgrowths (up to $1.5 \mathrm{~m}$ ) within rock salt were found in the borehole profile investigated. Those overgrowths often occurred in the form of anhydrite-halite rock in which anhydrite created a framework with cell spaces filled by halite (Fig. 3 ).

All sulphur isotopic compositions $\left(\delta^{34} S\right)$ were quite similar within a narrow range varying from +20.2 to $+22.7 \%$ (Table 1 ), with the lowest values below $+21 \%$ found in samples 1357 , 1354, and 1352 (Fig. 4). The average value of $\delta^{34} S$ amounted to $+21.4 \pm 0.3 \%$. A certain change in the regularity of $\delta^{34} S$ was observed as a trend but the number of analyses (10) was insufficient to specify such changes (Fig. 4).

\section{INTERPRETATION}

The main processes that lead to fractionation of sulphur isotopes in dissolved sulphate include primarily the following:

- crystallisation fractioning during sulphate precipitation;

- sulphate dissolution and reprecipitation (chemical recycling);

- bacterial reduction of sulphates. 


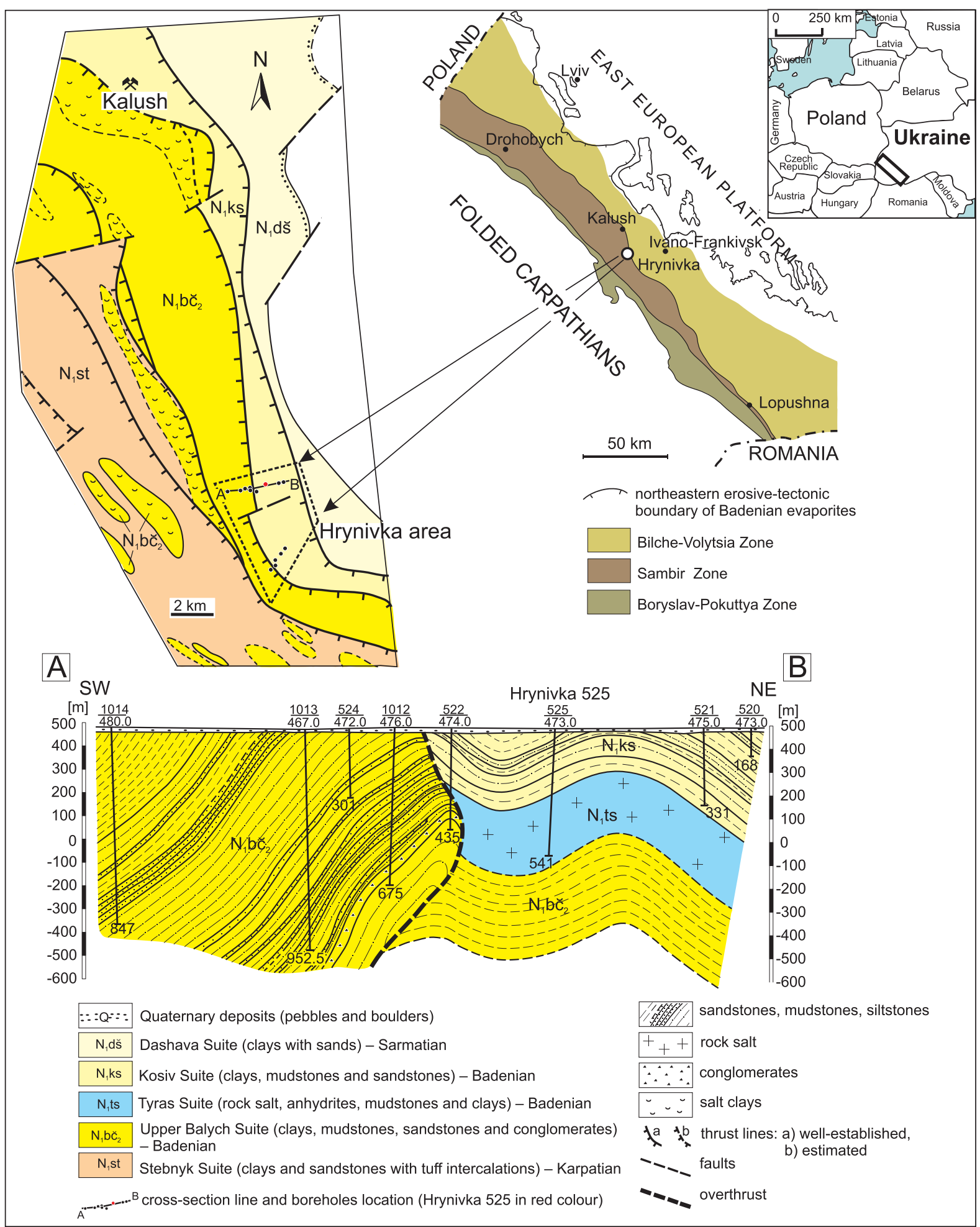

Fig. 2. Geological map of the Carpathian Foredeep in Kalush and Hrynivka areas, with a geological cross-section along line I-I (Stupnitskiy et al., 1978)

Tectonic subdivision of the Fore-Carpathian Basin after Vul et al. (1989)

During crystallisation of sulphates (gypsum, anhydrite, or potash-magnesium sulphates) from evaporated seawater, limited sulphur isotopic fractionation occurs. Ca-sulphate minerals become enriched with heavy sulphur isotope $(1.65 \pm 0.12 \%$ ) in comparison to parent brine (e.g., Thode and Monster, 1965; Holser and Kaplan, 1966; Nielsen, 1972; Holser, 1979). Experi- mental studies have shown that the fractional crystallisation $\left(\Delta \delta^{34} S_{\text {gypsum-sw }}\right)$ in sea water concentrated to the beginning of halite crystallisation amounts to $1.5 \pm 0.3 \%$ (Raab and Spiro, 1991).

The process of dissolution of previously deposited sulphate does not lead to isotopic fractionation. Sulphate redeposition causes further fractionating. Detailed studies of the Badenian 

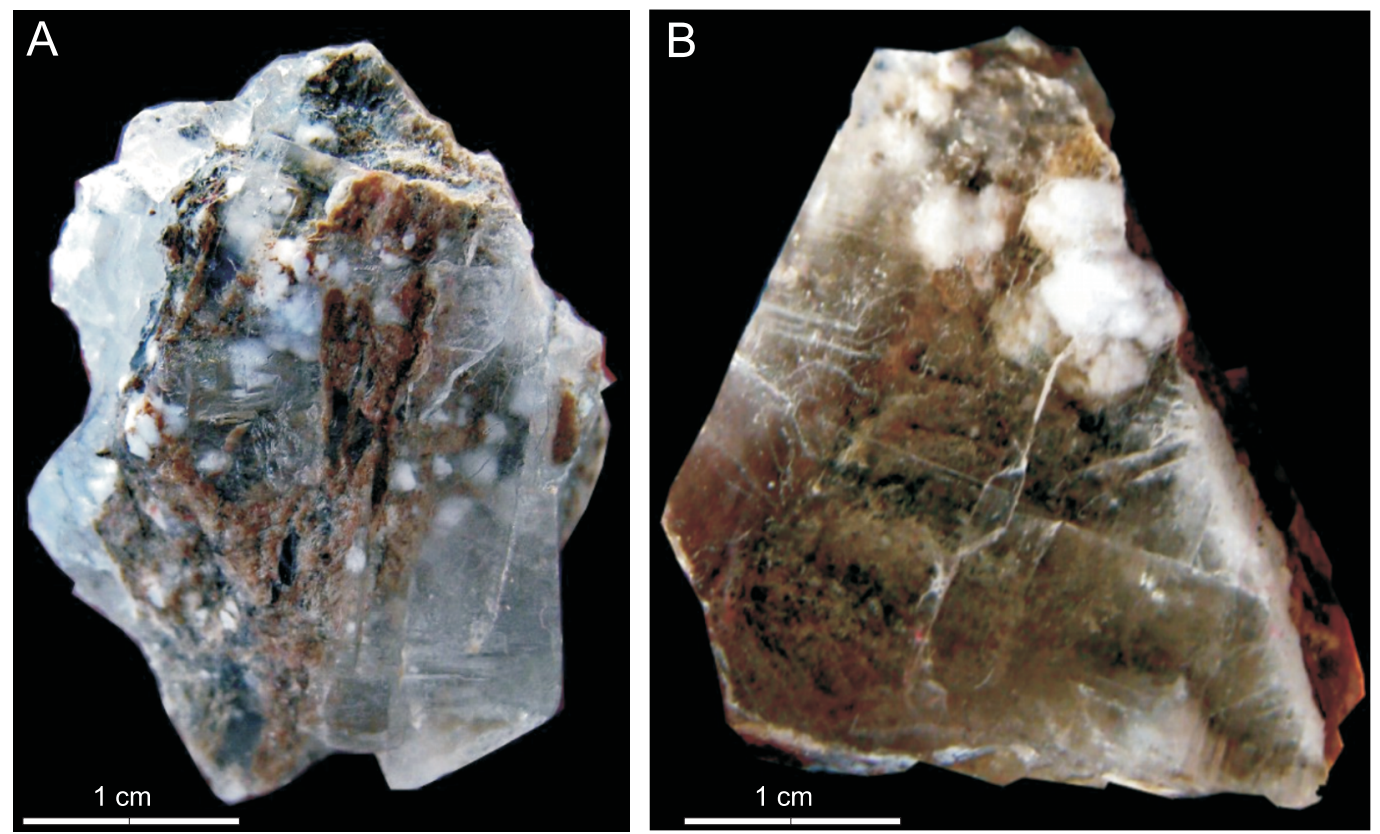

Fig. 3. Anhydrite nodules at the boundary of clay material and halite

A - coarse crystalline rock salt with intergranular thin concentrations of claystone material and nodules of anhydrite; B - single crystal of halite with white nodular anhydrite; Hrynivka, borehole 525, sample 1362 (depth 454-456 m)

The isotopic composition of sulphur in anhydrite, Hrynivka 525 borehole

\begin{tabular}{|c|c|c|c|c|c|c|c|c|c|c|}
\hline \multirow[t]{2}{*}{ Sample } & \multirow{2}{*}{$\begin{array}{l}\text { Depth } \\
\text { [m] }\end{array}$} & \multicolumn{3}{|c|}{$\begin{array}{l}\text { Content in solutions [g/l] } \\
\text { (mean in brackets) }\end{array}$} & \multicolumn{3}{|c|}{ Jänecke Unit [\%] } & \multirow[t]{2}{*}{ Anhydrite } & \multirow{2}{*}{$\begin{array}{c}\text { Br content } \\
\text { in halite } \\
\text { [ppm] }\end{array}$} & \multirow[t]{2}{*}{$\delta^{34} \mathrm{~S} \%{ }_{\text {CCDT }}$} \\
\hline & & $\mathrm{K}^{+}$ & $\mathrm{Mg}^{2+}$ & $\mathrm{SO}_{4}^{2+}$ & $2 \mathrm{~K}$ & $\mathrm{Mg}$ & $\mathrm{SO}_{4}$ & & & \\
\hline 1341 & 286 & $\begin{array}{c}8.1,10.4,7.9 \\
(8.8)\end{array}$ & $\begin{array}{l}26.8,33.1 \\
(30.0)\end{array}$ & $\begin{array}{c}26.1,27.9 ; 26.5 \\
21.9 \\
(25.6)\end{array}$ & 7.0 & 76.5 & 16.5 & nodular & 50 & 22.7 \\
\hline 1342 & 304 & $\begin{array}{c}8.5,7.0,7.4,6.7 \\
9.0,7.7,6.9,9.2 \\
(7.8)\end{array}$ & $\begin{array}{l}22.1,31.7,25.4 \\
24.7,31.9(27.2)\end{array}$ & $\begin{array}{l}21.4,22.5,23.1 \\
22.9,21.6(22.3)\end{array}$ & 6.9 & 77.1 & 16.0 & nodular & 40 & 21.7 \\
\hline 1345 & 314 & $\begin{array}{l}6.1,5.7 \\
(5.9)\end{array}$ & $\begin{array}{l}20.6,23.8 \\
(22.2)\end{array}$ & $\begin{array}{c}17.7,16.6,18.3 \\
(17.6)\end{array}$ & 6.4 & 77.9 & 15.6 & nodular & 40 & 21.2 \\
\hline 1350 & $342-343$ & & & & & & & massive & & 22.22 \\
\hline 1352 & 362 & $\begin{array}{c}8.3,8.8,8.1 \\
(8.4)\end{array}$ & $\begin{array}{c}28.5,27.6,23.3 \\
32.5,28.6,30.7 \\
(28.1)\end{array}$ & $\begin{array}{c}18.9,20.4,18.9 \\
19.3,22.3,19.0 \\
(19.8)\end{array}$ & 7.2 & 78.9 & 13.9 & nodular & 50 & 20.9 \\
\hline 1353 & 366 & $\begin{array}{c}4.6,4.8,6.3 \\
(5.2)\end{array}$ & $\begin{array}{l}20.2,20.8 \\
(20.5)\end{array}$ & $\begin{array}{c}14.3,13.4,13.6 \\
(13.8)\end{array}$ & 6.3 & 80.0 & 13.6 & nodular & 30 & 21.6 \\
\hline 1354 & 376 & $\begin{array}{l}5.2,6.1 \\
(5.7)\end{array}$ & $\begin{array}{c}20.9,23.2 \\
(21.7)\end{array}$ & $\begin{array}{c}\text { 13.6, } 17.6,14.0 \\
13.3,15.6,19.6 \\
(15.6)\end{array}$ & 6.5 & 79.1 & 14.4 & nodular & 40 & 20.2 \\
\hline 1357 & $410-411$ & $\begin{array}{c}7.7,8.2,6.5,8.8, \\
8.7,8.3(8.0)\end{array}$ & $\begin{array}{c}27.7,28.3,25.5 \\
(27.2)\end{array}$ & $\begin{array}{c}23.0,21.4,20.3 \\
(21.6)\end{array}$ & 7.1 & 77.4 & 15.6 & nodular & 30 & 20.5 \\
\hline 1362 & $454-456$ & $\begin{array}{c}6.3,7.1,7.8,7.9 \\
(7.3)\end{array}$ & $\begin{array}{c}26.8,25.0 \\
(25.9)\end{array}$ & $\begin{array}{l}23.8,22.2,20.0 \\
24.9,21.5(22.5)\end{array}$ & 6.7 & 76.5 & 16.8 & nodular & 20 & 21.58 \\
\hline 1365 & 480 & $\begin{array}{c}8.5,9.2 \\
(8.9)\end{array}$ & $\begin{array}{c}32.0,33.8,25.3 \\
(30.4)\end{array}$ & $\begin{array}{c}23.1,22.9,25.0 \\
(23.7)\end{array}$ & 7.1 & 77.6 & 15.3 & nodular & 40 & 21.8 \\
\hline \multicolumn{8}{|c|}{ Modern ocean water saturated to the beginning of crystallisation of: } & & \multirow{3}{*}{$\begin{array}{c}68 \\
200\end{array}$} & \multirow{3}{*}{$21.53-21.77$} \\
\hline & lite & 3.9 & 12.6 & 17.6 & 6.6 & 69.0 & 24.3 & & & \\
\hline \multicolumn{2}{|c|}{ epsomite } & 26.1 & 85.9 & 115.0 & 6.6 & 69.8 & 23.6 & & & \\
\hline
\end{tabular}

The composition of primary fluid inclusions in halite (Galamay, 2010) and bromine content in halite (Galamay, 2003) for the same samples: the content of ions in modern seawater (after McCaffrey et al., 1987); bromine content in primary halite after Holser (1979), bromine content in halite at the beginning of crystallisation of K-salts after Holser (1966), isotopic composition of modern seawater $\delta^{34} \mathrm{~S} \%{ }_{0 \mathrm{CDT}}+20 \% 0$ enriched to $1.65 \pm 0.12 \%$ (Raab and Spiro, 1991), isotopic composition for samples no. 1350 and 1362 (after Galamay, 1997) 


\section{Hrynivka 525}

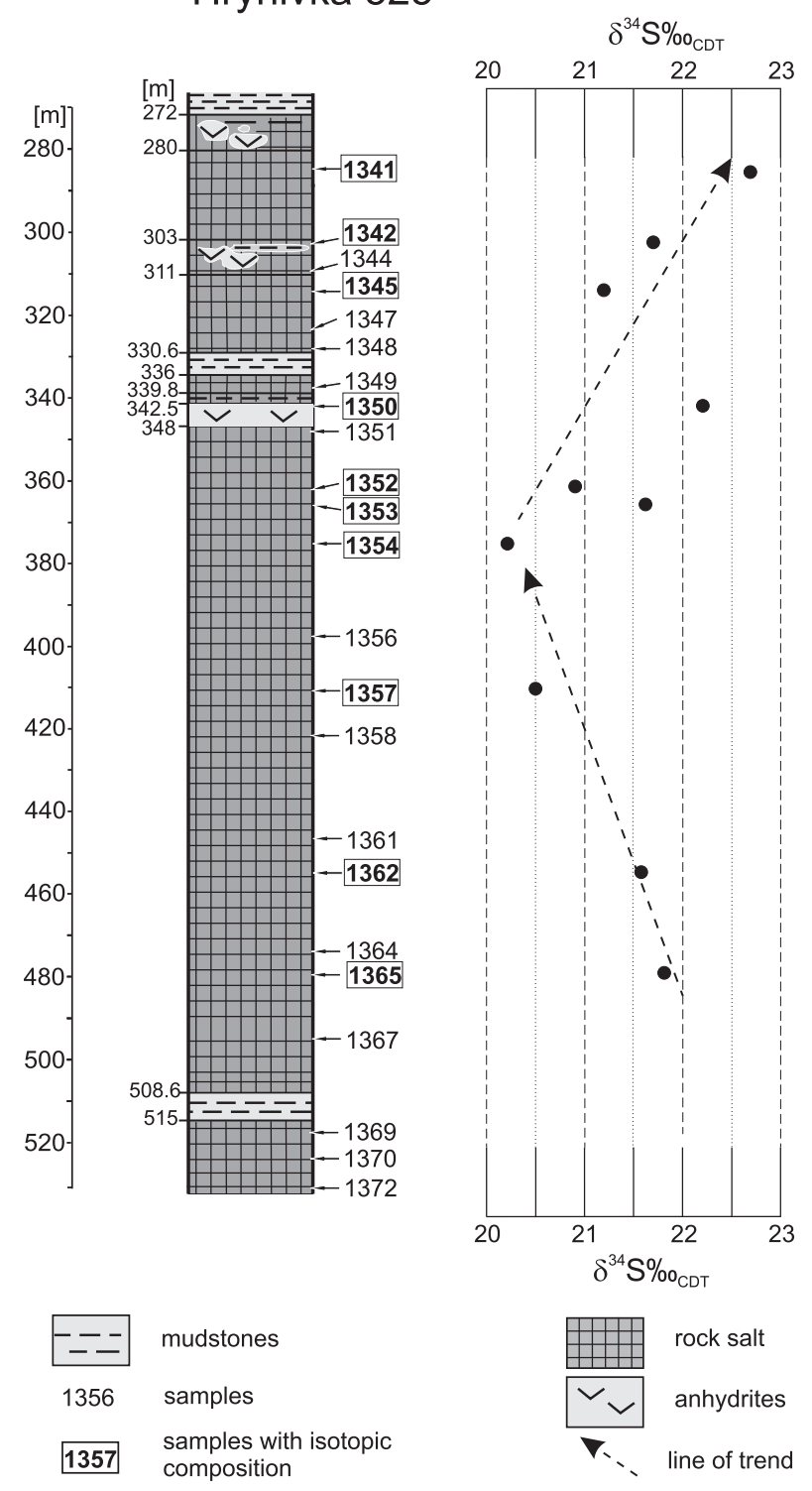

Fig. 4. Lithological profile of the Hrynivka 525 borehole, with the locations of samples and of $\delta^{34} \mathrm{~S}$ value determinations

gypsum in the Carpathian Foredeep (Peryt et al., 2002) showed a large variation of $\delta^{34} S$ (by 4.5-7.7\%), which was interpreted as redeposition of previously deposited marine gypsum.

The bacterial reduction of dissolved sulphate is suppressed in well-aerated waters (Grinenko and Grinenko, 1974) and the sulphur-reducing bacteria (Desulfovibrio) develop best at $\mathrm{pH}$ 6.3-8.6 (Postgate, 1960). According to Petrichenko (1988) and Petrichenko et al. (1997) evaporite basins of the Carpathian region and other salt-bearing basins were characterized by two factors: they were well-aerated and slightly acid conditions (Eh from +150 to $+450 \mathrm{mV}$; $\mathrm{pH} \mathrm{4.6-6.6)}$ prevailed in the basins, which definitely limited the sulphate reduction. Only periodically, brine Eh dropped below $150 \mathrm{mV}$ (Petrichenko, 1988). The isotope determinations provided in this study were carried out on anhydrite nodules generally found on the boundary of halite chevron crystals and clay matrix in chevron halite (Fig. 3). That means that anhydrite developed as a result of redistribution of matter (or partial recrystallisation of the cryptocrystalline gyp- sum mass of sedimentary origin) even at the stage of earlier diagenesis, in non-lithified deposits (Lobanova, 1956; Ivanov and Voronova, 1972). Thus, based on the $\delta^{34} S$ data, we do not assume any extensive development of bacterial sulphate reduction processes during early diagenesis.

When passing from early to late diagenesis of salt deposits, the Eh potential naturally shifted towards below zero values (Petrichenko, 1988). Sulphate reduction was indicated by the presence of very small (up to $50 \mu \mathrm{m}$ ) ball-shaped pyrite framboids (Hrynivka, borehole 525, sample 1354). Such framboids were found in the diagenetic halite and silt layers accompanying the rock salt. A constant presence of pyrite in the Hrynivka rock salt was also confirmed by X-ray analysis of the insoluble part of salt (Yaremchuk and Galamay, 2009). Besides, chemical recycling during diagenesis caused increase of $\delta^{34} S$ in anhydrite. The decrease of $\delta^{34} S$ in anhydrite was possibly due to influx of water with a high content of the light ${ }^{32} \mathrm{~S}$ isotope (Makhnach, 1999).

The isotopic composition of dissolved sulphate in modern sea water is $\delta^{34} S=20.0 \pm 0.25 \%$, based on numerous widerange analyses (from +19.3 to $+21.4 \%$; Raab and Spiro, 1991) and it is similar to the deduced composition of Miocene sea water (Thode et al., 1961; Posokhov, 1975; Claypool et al., 1980; Cendón et al., 2004).

The average value of $\delta^{34} S$ in anhydrite of $+21.4 \pm 0.3 \%$ obtained in this study suggests that the isotopic composition of dissolved sulphate in the salt-bearing basin of the Hrynivka area amounted to $\delta^{34} S=19.8 \%$ o $(21.4 \% 0-1.65 \pm 0.12 \%)$, which approximately corresponds to the isotopic composition of present-day seawater. Our results indicate that the main process of sulphur isotope fractionation in forming the Hrynivka anhydrite occurred during gypsum crystallisation from the basin brine. Other fractionation of sulphur isotopes only slightly affected $\delta^{34} \mathrm{~S}$ anhydrite (as discussed below).

In the Hrynivka area, the chemical composition of brine and the total concentration did not change significantly during the salt accumulation processes. That indicated periodic inflows of marine waters into the basin (Galamay, 2010). The chemical composition of fluid inclusions in halite (in ten samples studied) generally indicated a marine origin for the sedimentary brine (Fig. 5). The average ratio between $2 \mathrm{~K}, \mathrm{Mg}, \mathrm{SO}_{4}$ was $6.9,77.4$, and $15.7 \%$, respectively (Jänecke unit) (Galamay, 2010). Those results were similar to the chemical composition of the Badenian sea water saturated to halite precipitation: $2 \mathrm{~K}-7.8 \%$; $\mathrm{Mg}-77.2 \%$, and $\mathrm{SO}_{4}-15.0 \%$ (Jänecke unit; Kovalevich and Vovnyuk, 2010).

In the interval $362-410 \mathrm{~m}$ of the Hrynivka 525 borehole, the chemical composition of primary fluid inclusions in halite was characterized by the lowest content of sulphate ions (Table 1, samples 1352, 1353, 1354, and 1357). Therefore, the points corresponding to the chemical composition of fluid inclusions in samples 1352, 1353, and 1354 were placed in the upper part of the Jänecke diagram (Fig. 6). The reduction of $\mathrm{SO}_{4}^{2-}$ ion content in brine was an effect of the nucleation of a large number of small gypsum crystals, owing to the interaction of sulphate brine with waters containing $\mathrm{Ca}\left(\mathrm{HCO}_{3}\right)_{2}$ (Valyashko and Pelsh, 1952; Valyashko, 1962).

The location of points indicative of the chemical composition of fluid inclusions from sample 1357 on the diagram (situated below 1352, 1353 and 1354 point locations) is a reflection of the fact that the local reduction of magnesium ion content occurred with respect to sulphate in brine (formation of a jelly mass, whose composition is close to the formula of $2 \mathrm{MgO} \cdot \mathrm{CO}_{2}$. $4 \mathrm{H}_{2} \mathrm{O}$, and fine rhombohedral crystals of dolomite). It is known that mixing sulphate-rich brine with waters containing $\mathrm{Ca}\left(\mathrm{HCO}_{3}\right)_{2}$ (so-called desulfuration, or metamorphisation of 


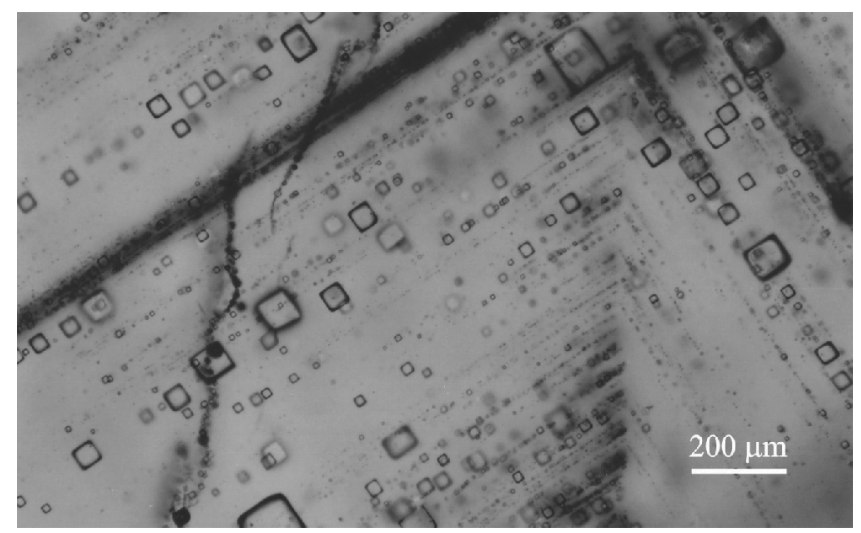

Fig. 5. The sedimentation structure of halite (chevron), formed with primary fluid inclusions

There are fluid inclusions (containment failure along a crack) on the left-hand side of the structure which contains a gas phase;

Hrynivka, borehole 525, sample 1361 (depth 444-448 m)

sulphate-rich brine) causes mass crystallisation of fine crystals of gypsum, dolomite, and $2 \mathrm{MgO} \cdot \mathrm{CO}_{2} \cdot 4 \mathrm{H}_{2} \mathrm{O}$ (Valyashko and Pelsh, 1952). At the same time, intense precipitation of $2 \mathrm{MgO}$. $\mathrm{CO}_{2} \cdot 4 \mathrm{H}_{2} \mathrm{O}$ takes place owing to high alkalinity of the brine. In the deposits, $2 \mathrm{MgO} \cdot \mathrm{CO}_{2} \cdot 4 \mathrm{H}_{2} \mathrm{O}$ turns into dolomite. A high dolomite content (ca. 7.5\%) was another characteristic feature identified in the mud fraction of sample 1357 (Galamay, 2012).

Many small crystals of gypsum, anhydrite, and bassanite were observed in the fluid inclusions in halite of some samples (Fig. 6B). We could also observe anhydrite crystals, concentrated along the growth zones of sedimentation halite (Galamay, 2012). Quite often, such multi-phase fluid and stable inclusions were deposited only on one of the chevron edges (Fig. 7).

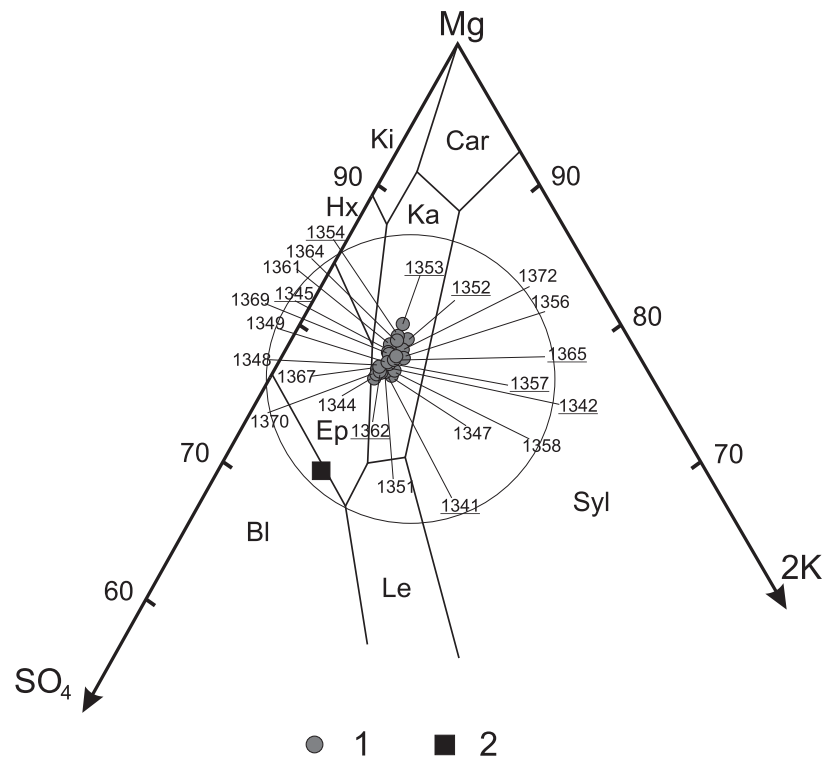

In the inter-crystalline space of the chevron crystals and between halite growths, clay material was often observed (samples 1352, 1353, 1354, and 1357). Samples 1352 and 1354 were characterized as the richest in terrigenous clay material. In our opinion, the decreased $\delta^{34} \mathrm{~S}$ values in anhydrite in three of four samples from interval 410-362 m (samples 1352, 1354, and 1357) are due to the inflow of continental waters, which were rich in the light ${ }^{32} \mathrm{~S}$ isotope. Therefore, we conclude that the salts from the interval 410-362 m (Table 1 and Fig. 4) were crystallised from marine sulphate brine during intense inflow of continental waters into the basin.

Palaeogeographic reconstructions (Fig. 1) suggest that the deposition of salts in the Hrynivka area resulted from crystallisation from seawater. Sea water was mostly devoid of $\mathrm{Ca}\left(\mathrm{HCO}_{3}\right)_{2}$ (because of calcium carbonate and calcium sulphate precipitation in the outer parts of the evaporite basin). The influence of continental runoff resulted in terrigenous material input, metamorphisation of the sulphate-rich brine, and decrease of $\delta^{34} \mathrm{~S}$ in the anhydrite.

Dissolved sulphate from freshwater and rainfall (as compared to seawater) contained significantly more of the light ${ }^{32} \mathrm{~S}$ isotope, as demonstrated by other authors (e.g., Vinogradov et al., 1962; Yeremenko and Pankina, 1971). For example, continental runoff had a profound effect on the water of the modern Black, Azov, and Caspian seas. So, the sea water near the coast of the Black Sea has $\delta^{34} S=+18.9 \%$, while the isotopic composition of dissolved sulphate of the Black Sea in general is $\delta^{34} S=+19.3 \%$. The sea water of the Azov Sea near Kerch has a value of $\delta^{34} S=+15.5 \%$ (Yeremenko and Pankina, 1971). The isotopic composition of dissolved sulphate in the Caspian Sea, which has no connection with the ocean, is $+8.6 \%$.

The typical bromine content in a marine-derived halite at the beginning of its crystallisation is ca. $68 \mathrm{ppm}$ (Holser, 1979), or 50-60 ppm (Valyashko and Mandrykina, 1952). In the investigated sedimentary halite bromine content was quite low (20-50 ppm, Table 1). A low bromine content in the halite of the

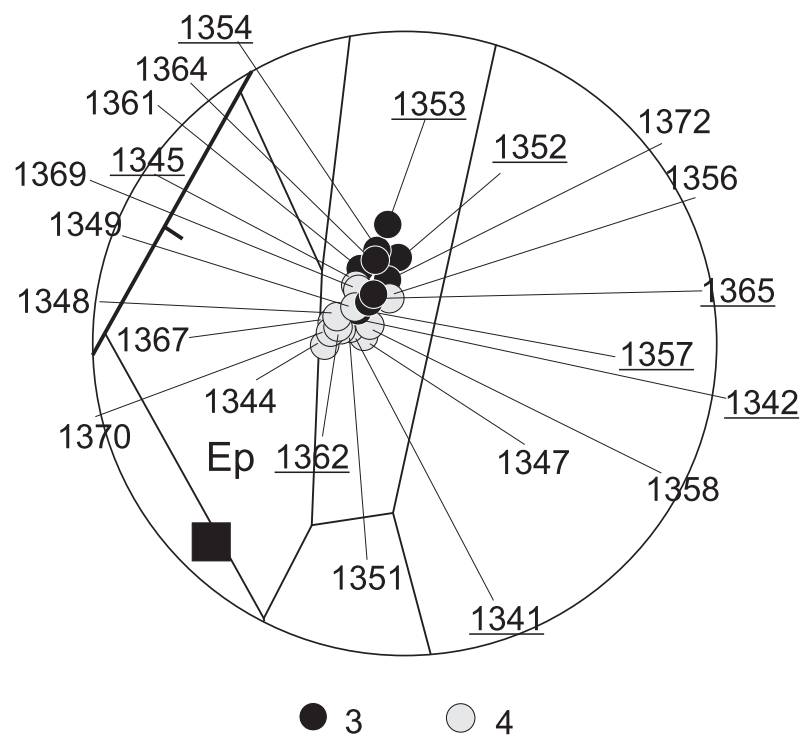

Fig. 6. Chemical composition of brine in primary inclusions in halite shown on a Jänecke diagram (for sea water, at a temperature of $25^{\circ} \mathrm{C}$ )

Chemical composition of brine in primary fluid inclusions in halite; Hrynivka, borehole 525 (Galamay, 2010 ), 1 - chemical composition points of fluid inclusions, 2 - chemical composition point of modern sea water saturated to the beginning of halite crystallisation (McCaffrey et al., 1987); small crystals of anhydrite between zones of sedimentary halite and gypsum, bassanite and anhydrite in primary fluid inclusions in halite for each of the samples (Galamay, 2012); 3 - a considerable amount of crystals; 4 - a small amount, or an absence of crystals 


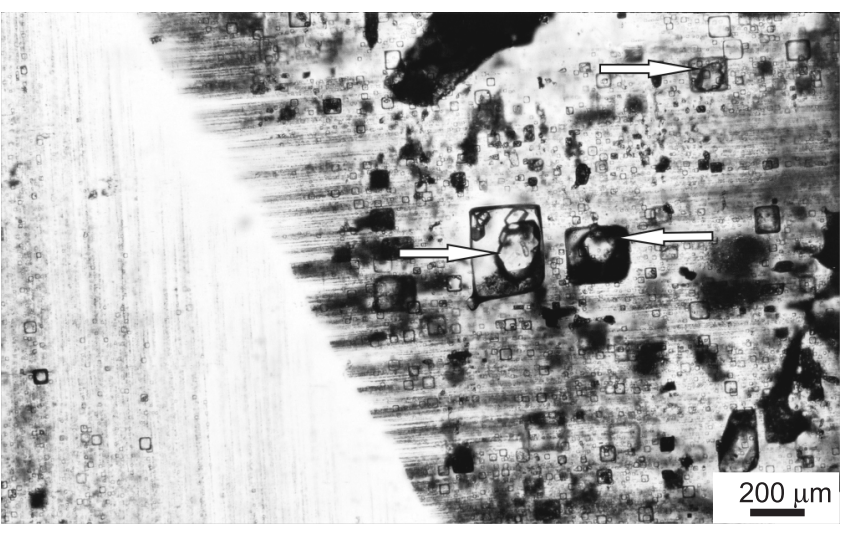

Fig. 7. Multi-phase fluid inclusions with gypsum, bassanite, and anhydrite crystals, or terrigenous material

Arrows indicate large fluid inclusion, with gypsum crystals; Hrynivka, borehole 525, sample 1354

samples studied indicates that redeposition of halite occurred in the salt-bearing basin and that contributions of both marine and continental waters a effected $\mathrm{Br}$ concentrations in the precipitated halite.

The strontium isotope ratio $\left({ }^{87} \mathrm{Sr} /{ }^{86} \mathrm{Sr}\right)$ in one anhydrite sample from the Hrynivka 525 borehole (no. 1354) (Peryt et al., 2010) gave a value of 0.708902 . That ratio is slightly higher than the ratios expected for Badenian sea water (0.708800-0.708809; McArthur et al., 2001). The relatively slightly radiogenic ${ }^{87} \mathrm{Sr} /{ }^{86} \mathrm{Sr}$ ratio of anhydrite sample 1354 may have been derived from clay intercalations in the rock salt (Peryt et al., 2010), and so evidence of continental water inflow to the salt-bearing basin.

\section{DISCUSSION}

The average sulphur isotopic composition $\left(\delta^{34} S\right)$ of the anhydrite from the Carpathian Foredeep and East Slovak basins ranges between +21.5 and $+22.5 \%$ (Table 2 ). The determination of $\delta^{34} S$ for the anhydrite of the salt succession shown on the diagram (Fig. 8) indicates a narrow range of the values for sixty samples. In the case of five determinations, the values were clearly diverse. The lowest of these were obtained from nodular anhydrite originating from zubers of the Bochnia Salt Mine (+18.78\%, sample 1; Bukowski and Szaran, 1997) and the Zbudza salt deposit in the East Slovak Basin (18.28\%, sample P7/2; Kasprzyk and Bukowski, 2009). Those low values $\left(\delta^{34} S\right)$ probably resulted from the delivery of sulphate ions to the basin, enriched with light sulphur isotopes, originating from meteoric waters and containing oxidised sulphur compounds. This was confirmed by the presence of carbonised plant matter in the Zbudza anhydrite sample, as well as by very low bromine content $(5.8 \mathrm{ppm})$ in the halite occurring directly above the anhydrite (Bukowski et al., 2007).

Then, the values of $\delta^{34} S$ amounting to $+24.4 \%$ ( $Z$ budza, sample P-6/24; Kasprzyk and Bukowski, 2009), +25.4\%o (Bochnia, sample 23; Bukowski and Szaran, 1997), and $+24.0 \%$ (Wieliczka, sample A-8-W; Bukowski and Szaran, 1997) were characteristic of late diagenetic varieties of gypsum and anhydrite (sulphate dissolution and re-precipitation; bacterial reduction of sulphates). Those samples were also lithologically different from the remaining ones (fibrous gypsum filling crevices, inner anhydrite filling the layer shear planes, and anhydrite aggregates with small crystals of xenomorphous halite in the silty matrix).

The extremely high values and extremely low values were not taken into account in calculating the $\delta^{34} S$ in dissolved sulphates of the Badenian sea water of the Central Paratethys.

Based on sixty determinations of $\delta^{34} S$ in anhydrite (average ${ }^{34} \mathrm{~S}=+22.0 \%$ ) and taking into account isotopic fractionation during Ca-sulphate crystallisation $(22.0 \%-1.65 \pm 0.12 \%$ ), we could determine that the average $\delta^{34} S$ of dissolved sulphate in sea water of the Central Paratethys was $+20.3 \%$. This composition is comparable to the isotopic composition of dissolved sulphate in present-day sea water and the values established for the Badenian evaporite basin brine of the Carpathian Foredeep $\left(\delta^{34} S=+20.6 \%\right.$ ) (Kasprzyk, 1997). The $\delta^{34} S$ value for the Badenian sea water may actually have been slightly higher if we consider potential changes to the brine composition of salt-bearing basins caused by inflow of continental waters enriched in light ${ }^{32} \mathrm{~S}$ isotopes.

The results presented here are generally consistent with the majority of chemical composition determinations of fluid inclusions in halite obtained by the ultramicrochemical method developed by Petrychenko (1973). In the majority of the Badenian evaporite basins, the composition and the proportions of main

Table 2

Sulphur isotopic composition in anhydrite from the Badenian salt-bearing deposits of the Carpathian region

\begin{tabular}{|c|c|c|c|c|c|}
\hline \multirow{2}{*}{ Basin } & \multirow{2}{*}{ Location } & \multirow{2}{*}{$\begin{array}{l}\text { Number } \\
\text { of samples }\end{array}$} & Range & Mean & \multirow{2}{*}{ References } \\
\hline & & & ${ }^{34} \mathrm{~S} \%$ oCDT & ${ }^{34} \mathrm{~S} \%{ }_{0 \mathrm{CDT}}$ & \\
\hline \multirow{10}{*}{$\begin{array}{l}\text { Carpathian } \\
\text { Foredeep }\end{array}$} & \multirow{2}{*}{ Hrynivka, borehole 525} & 8 & $20.20-22.70$ & 21.32 & New data \\
\hline & & 2 & $21.58-22.22$ & 21.90 & Galamay (1997) \\
\hline & Zabolotiv, borehole 4038 & 1 & 21.60 & 21.60 & Galamay (1997) \\
\hline & Slanic Prahova & 3 & $20.27-21.12$ & 20.78 & Galamay (1997) \\
\hline & Barycz, borehole 962 & 2 & $21.47-22.36$ & 21.91 & Bukowski and Szaran (1997) \\
\hline & Wieliczka & 8 & $21.45-24.03$ & 22.62 & Bukowski and Szaran (1997) \\
\hline & Wieliczka & 4 & $21.90-22.80$ & 22.40 & Parafiniuk and Halas (1997) \\
\hline & Wieliczka & 3 & $21.6-21.9$ & 21.77 & Claypool et al. (1980) \\
\hline & Bochnia & 7 & $18.78-25.36$ & 21.75 & Bukowski and Szaran (1997) \\
\hline & Wojnicz, borehole IG 4 & 14 & $22.01-23.20$ & 22.61 & Cendón et al. (2004) \\
\hline East Slovakian & Zbudza, well Ep-2 & 3 & $21.77-21.98$ & 21.85 & Galamay (1997) \\
\hline & Zbudza, well P-6, P-7 & 10 & $18.28-24.45$ & 22.22 & Kasprzyk and Bukowski (2009) \\
\hline
\end{tabular}




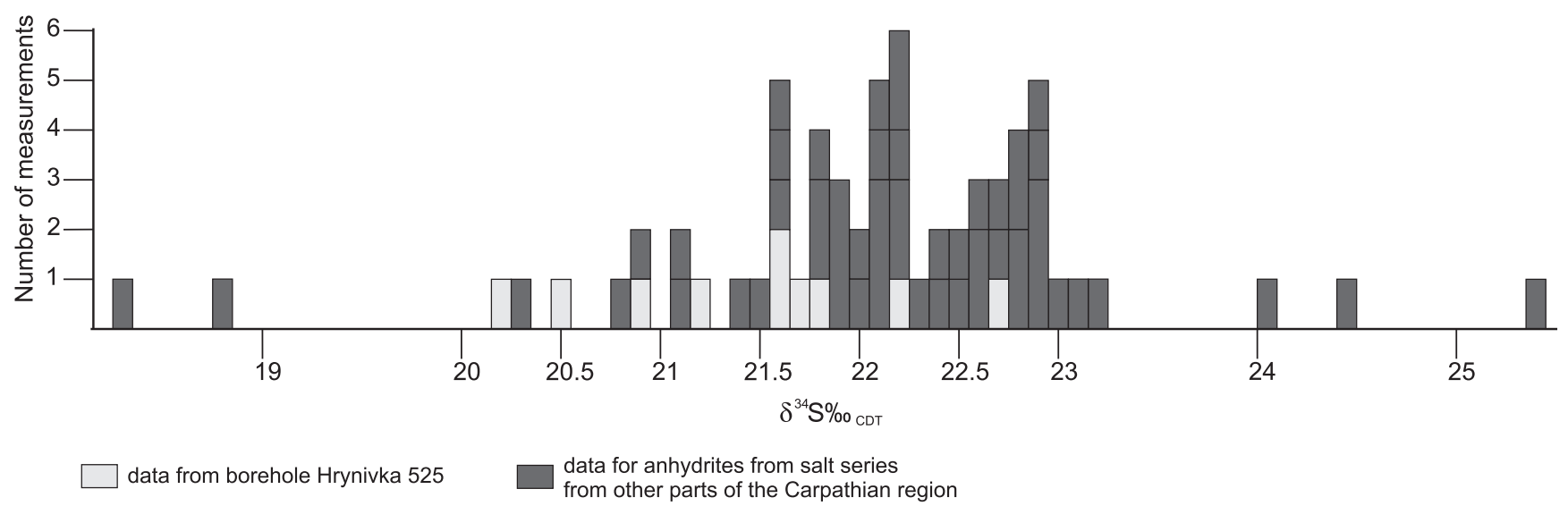

Fig. 8. Sulfur isotopic composition in anhydrite from the Badenian salt deposits of the Carpathian region

The diagram shows new and previously published data (Claypool et al., 1980; Galamay, 1997; Bukowski and Szaran, 1997; Parafiniuk and Halas, 1997; Cendón et al., 2004; Kasprzyk and Bukowski, 2009)

ions in the fluid inclusions indicated a marine origin for the brines (Bukowski, 2011 with references therein). However, local inflows of continental waters were also identified (Kovalevich and Petrichenko, 1997; Galamay, 2001; Galamay and Bukowski, 2011).

Studies of the chemical composition of fluid inclusions, bromine content in halite, and the isotopic composition of sulphur and oxygen in anhydrite were made on rock salt of the Wojnicz area in the Polish Carpathian Foredeep by Cendón et al. (2004). Modelling based on the results of those studies indicated that, during halite precipitation in the Carpathian Foredeep, continental waters amounted to as much as $65-70 \%$, with only $20-30 \%$ sea water and $5-10 \%$ brine originating from previously dissolved halite (Cendón et al., 2004). The chemical composition of fluid inclusions in the halite was the basis of modelling. The data were obtained with a modern precise method (Cryo-SEM-EDS) and studies of fluid inclusions in halite. Those data indicated that the average ratios of $2 \mathrm{~K}, \mathrm{Mg}$, and $\mathrm{SO}_{4}$ in brine (samples $\mathrm{WJ}-3$, WJ-13, WJ-18, WJ-41; Cendón et al., 2004) were 6.9, 75.2 and $17.9 \%$, respectively (Jänecke unit). This chemical composition was typical of Badenian marine brine (Galamay and Bukowski, 2011; Bukowski, 2011). However, the chemical composition of the fluid inclusions of other samples (WJ-22, WJ-26, WJ-3B, WJ-36; Cendón et al., 2004) was different from those presented above. In some of the samples, we observed anomalously low concentrations of $\mathrm{K}^{+}$ions. For example, in sample WJ-22, the potassium content was below the limit of quantification, which was interpreted as a result of a local reaction of brine with calcium sulphate to precipitate polyhalite (Cendón et al., 2004). That hypothesis was corroborated by the local presence of polyhalite at various levels throughout the borehole (Cendón et al., 2004). In that case, anhydrite or gypsum were transformed into polyhalite through reaction with marine brine of high concentration. Consequently, the chemical composition of the parent brine could be changed under local conditions and the ion ratios in primary fluid inclusions not reflect "typical Badenian brine" (e.g., Kovalevich and Petrichenko, 1997; Galamay, 2001; Galamay and Bukowski, 2011).

The sulphur isotope compositions of anhydrite from Wojnicz (Cendón et al., 2004) were similar to the data available from other parts of the salt basin (Table 2). The results were almost constant with a range of $\delta^{34} \mathrm{~S}=+22.0 \%$ o to $+23.2 \%$, and on average of $\delta^{34} S=+22.6 \%$. To explain that isotopic composition corresponding to the isotopic composition of marine origin, Cendón et al. (2004) suggested that the isotopic values of $\delta^{34} S$ were not always explicit indications of the sulphate origin. In conditions of sea water mixing with meteoric waters saturated with halite, sulphates could crystallise and produce isotopic values similar to $\delta^{34} S=22 \%$, being basically not very different from typical marine-origin sulphates (Ayora et al., 1994; Cendón et al., 2004). Such interpretation would require confirmation for instance by chlorine isotope studies of halite (Eastoe and Peryt, 1999; Eastoe et al., 2007, though see e.g., García-Veigas et al., 2009).

\section{CONCLUSIONS}

The $\delta^{34} S$ values in the Hrynivka anhydrite range from $+20.2 \%$ o to $+22.7 \%$. Those values are consistent with the results of chemical composition studies of primary fluid inclusions in halite, performed by ultramicrochemical method (Petrychenko, 1973) and indicate that sea water had been the main source of solutes in the basin.

The sulphur isotope content of the anhydrite indicates a marine origin for the sulphate, though this not synonymous with a marine basin. At different stages of salt accumulation, we could infer inflows of continental waters in to the basin, with a lighter isotopic sulphate composition (as supported by data from the Hrynivka, Bochnia, and Zbudza deposits).

The $\delta^{34} S$ value of the Badenian sea water of the Central Paratethys was calculated from sixty values and the determinations of sulphur isotopic composition for anhydrite of the Carpathian region was approximately $+20.3 \%$. The $\delta^{34} S$ value for the Badenian ocean water may actually have been slightly higher if we consider potential changes of the brine composition of salt-bearing basins caused by inflow of continental waters enriched in light ${ }^{32} \mathrm{~S}$ isotopes.

Acknowledgements. This investigation was supported by the Major State Basic Research Development Program (973 no. 2011CB403007), National Natural Science Foundation of China (No: 40703018; 41173051; 41172131) and The Bureau of International Co-operation of the Chinese Academy of Sciences as well as through statutory funds of the AGH University of Science and Technology (project No. 11.11.140.320). The determinations of the isotopic composition of sulphur were made by Dr. Feng Lianjun in the Nanjing Institute of Geology and Geophysics, Chinese Academy of Sciences (IGGCAS). We also sincerely thank Dr. D. I. Cendón, Prof. T. Peryt, and in particular an anonymous reviewer for their comments and suggestions which improved the text. 


\section{REFERENCES}

Andreyeva-Grigorovich, A.S., Oszczypko, N., Savitskaya, N.A., Ślaczka, A., Trofimovich, N.A., 2003. Correlation of Late Badenian salts of the Wieliczka, Bochnia and Kalush areas (Polish and Ukrainian Carpathian Foredeep). Annales Societatis Geologorum Poloniae, 73: 67-89.

Ayora, C., García-Veigas, J., Pueyo, J.J., 1994. X-ray microanalysis of fluid inclusions and its application to the geochemical modeling of evaporite basins. Geochimica et Cosmochimica Acta, 58: 43-55.

Bukowski, K., 2011. Badenian saline sedimentation between Rybnik and Dębica based on geochemical, isotopic and radiometric research (in Polish with English summary). Dissertations Monographs, 236.

Bukowski, K., Szaran, J., 1997. Zawartość izotopów tlenu i siarki w anhydrytach z serii solonośnej Wieliczki i Bochni (in Polish). Przegląd Geologiczny, 45: 816-818.

Bukowski, K., Czapowski, G., Karoli, S., Bąbel, M., 2007. Sedimentology and geochemistry of the Middle Miocene (Badenian) salt-bearing succession from East Slovakian Basin (Zbudza Formation). Geological Society Special Publications, 285: 247-264.

Cendón, C.I., Peryt, T.M., Ayora, C., Pueyo, J.J., Taberner, C., 2004. The importance of recycling processes in the Middle Miocene Badenian evaporite basin (Carpathian Foredeep): palaeoenvironmental implications. Palaeogeography, Palaeoclimatology, Palaeoecology, 212: 141-158.

Claypool, G.E., Holser, W.T., Kaplan, I.R., Sakai, H., Zak, I., 1980. The age curves of sulfur and oxygen isotopes in marine sulphate and their mutual interpretation. Chemical Geology, 28: 199-260.

Eastoe, C.J., Peryt, T., 1999. Stable chlorine isotope evidence for non-marine chloride in Badenian evaporites, Carpathian mountain region. Terra Nova, 11: 118-123.

Eastoe, C.J., Peryt, T.M., Petrychenko, O.Y., Geisler-Cussey, D., 2007. Stable chlorine isotopes in Phanerozoic evaporites. Applied Geochemistry, 22: 575-588.

Galamay, A.R., 1997. Origin of the middle Miocene Badenian salts in the Carpathian region (in Polish with English summary). Przegląd Geologiczny, 45: 1012-1017.

Galamay, A.R., 2001. Fiziko-khimichnii umovi formuvannya badenskih yevaporitovih vidkladiv Karpatskogo regionu (in Ukrainian). Avtoref. dis. kand. gyeol. nauk: 04.00.02 - Gyeokhimiya. IGGGK NAN Ukraini, Lviv.

Galamay, A.R., 2003. Bromine contents in halite from the Badenian salt deposits of the Carpathian region as indicator of their genesis and terms of forming (in Ukrainian with English summary). Geologiya i Geokhimiya Goryuchikh Iskopayemykh, (3-4): 102-111.

Galamay, A.R., 2010. Physico-chemical conditions of the formation of the Badenian salt deposits of the Ukrainian Precarpathia (Grynivka area) (in Ukrainian with English summary). Geologiya i Geokhimiya Horyuchykh Kopalyn, (2): 64-77.

Galamay, A.R., 2012. Influence of continental run-off on composition of marine brines of Badenian salt basin central part (Ukrainian Fore-Carpathians) (in Ukrainian with English summary). Mineralogychnyi zbirnyk, 62: 228-235.

Galamay, A.R., Bukowski, K., 2011. Chemical composition of Badenian brines from primary fluid inclusions in halite (Transcarpathian Basin, Ukraine) (in Polish with English summary). Geologia, 37: 245-267.

García-Veigas, J., Rosell, L., Zak, I., Playà, E., Ayora, C., Starinsky, A., 2009. Evidence of potash salt formation in the Pliocene Sedom Lagoon (Dead Sea Rift, Israel). Chemical Geology, 265: 499-511.

García-Veigas, J., Cendón, D.I., Pueyo, J.J., Peryt, T.M., 2011. Zechstein saline brines in Poland, evidence of overturned anoxic ocean during the Late Permian mass extinction event. Chemical Geology, 290: 189-201.
Grinenko, V.A., Grinenko, L.N., 1974. Geokhimiya izotopov sery (in Russian). Nauka, Moskva.

Halas, S., Szaran, J., 1999. Low temperature thermal decomposition of sulphates to $\mathrm{SO}_{2}$ for on-line ${ }^{34} \mathrm{~S} /{ }^{32} \mathrm{~S}$ analysis. Analytical Chemistry, 71: 3254-3257.

Holser, W.T., 1966. Bromide geochemistry in salt rocks. Second Symposium on Salt. Northern Ohio Geological Society: 248-275.

Holser, W.T., 1979. Trace elements and isotopes in evaporites. Mineralogical Society of America Reviews in Mineralogy, 6: 295-346.

Holser, W.T., Kaplan, I.R., 1966. Isotope geochemistry of sedimentary sulphates. Chemical Geology, 1: 131-135.

Hryniv, S.P., Dolishniy, B.V., Khmelevska, O.V., Poberezhskyy, A.V., Vovnyuk, S.V., 2007. Evaporites of Ukraine: a review. Geological Society Special Publications, 285: 309-334.

Ivanov, A.A., Voronova, M.L., 1972. Galogennyye formatsii (in Russian). Nedra. Moskva.

Jasionowski, M., Peryt, T.M., 2010. Isotopic composition of dolomite associated with Middle Miocene Badenian anhydrites in the Carpathian Foredeep Basin of SE Poland. Geological Quarterly, 54 (4): 533-548.

Kasprzyk, A., 1997. Oxygen and sulphur isotope composition of Badenian (Middle Miocene) gypsum deposits in southern Poland: a preliminary study. Geological Quarterly, 41 (1): 53-60.

Kasprzyk, A., Bukowski, K., 2009. The isotopic composition of oxygen and sulphur of Badenian sulphates from the Zbudza salt deposit (Slovakia) (in Polish with English summary). Geologia, 35: 373-391.

Khrushchov, D.P., 1980. Litologiya i geokhimiya galogennykh formatsiy Predkarpatskogo progiba (in Russian). Naukova Dumka, Kiev.

Korenevskii, S.M., Zaharova, V.M., Shamahov, V.A., 1977. Miotsenovye galogennye formatsii pregorii Karpat (in Russian). Nedra, Leningrad.

Kovalevich, V.M., Petrichenko, O.I., 1997. Chemical composition of brines in Miocene evaporite basins of Carpathian region. Slovak Geological Magazine, 3: 173-180.

Kovalevych, V., Vovnyuk, S., 2010. Fluid inclusions in halite from marine salt deposits: are they real micro-droplets of ancient seawater? Geological Quarterly, 54 (4): 401-410.

Lobanova, V.V., 1956. Voprosy petrografii kaliynykh zalezhey Vostochnogo Predkarpatya (in Russian). Trudy VNIIG, 32: 164-214.

Lloyd, R.M., 1968. Oxygen isotope behavior in the sulphate-water system. Journal of Geophysical Research, 73: 6099-6110.

Longinelli, A., 1979. Isotope geochemistry of some Messinian evaporites: paleoenvironmental implications. Palaeogeography, Palaeoclimatology, Palaeoecology, 29: 95-123.

Makhnach, A.A., 1999. Geochemical evaluation of the transformation of anhydrite into gypsum (in Russian with English summary). Doklady Natsionalnoy Akademii Nauk Belarusi, 43: 90-93.

McArthur, J.M., Howarth, R.J., Bailey, T.R., 2001. Strontium isotope stratigraphy: LOWESS Version 3: best fit to the marine Sr-isotope curve for 0-509 $\mathrm{Ma}$ and accompanying lookup table for deriving numerical age. Journal of Geology, 109: 155-170.

McCaffrey, M.A., Lazar, B., Holland, H.D., 1987. The evaporation path of seawater and the coprecipitation of $\mathrm{Br}$ and $\mathrm{K}$ with halite. Journal of Sedimentary Petrology, 57: 928-937.

Nielsen, H., 1972. Sulphur isotopes and the formation of evaporite deposits. In: Geology of Saline Deposits (ed. G. Richter-Bernburg). Earth Sciences, 7: 91-102.

Oszczypko, N., Krzywiec, P., Popadyuk, I., Peryt, T., 2006. Carpathian Foredeep Basin (Poland and Ukraine). Its sedimentary, structural, and geodynamic evolution. AAPG Memoir, 84: 293-350.

Parafiniuk, J., Hałas, S., 1997. Sulfur and oxygen isotope composition as the genetic indicator for celestite from the Miocene 
evaporites of the Carpathian Foredeep. Slovak Geological Magazine, 3: 131-134.

Peryt, T.M., 2006. The beginning, development and termination of the Middle Miocene Badenian salinity crisis in Central Paratethys. Sedimentary Geology, 188-189: 379-396.

Peryt, T.M., Hałas, S., Karoli, S., Peryt, D., 1997. Isotopic record of environmental changes during deposition of Badenian (Middle Miocene) gypsum at Kobeřice near Opava (Czech Republic) (in Polish with English summary). Przegląd Geologiczny, 45: 807-810.

Peryt, T.M., Peryt, D., Szaran, J., Hałas, S., Jasionowski, M., 1998. Middle Miocene Badenian anhydrite horizon in the Ryszkowa Wola 7 borehole (southeast Poland) (in Polish with English summary). Biuletyn Państwowego Instytutu Geologicznego, 379: 61-78.

Peryt, T.M., Szaran, J., Jasionowski, M., Hałas, S., Peryt, D., Poberezhskyy, A., Karoli, S., Wójtowicz, A., 2002. S and O isotopic composition of the Middle Miocene Badenian sulphates in the Carpathian Foredeep. Geologica Carpathica, 53: 391-398.

Peryt, T.M., Hryniv, S.P., Anczkiewicz, R., 2010. Strontium isotope composition of Badenian (Middle Miocene) Ca-sulphate deposits in West Ukraine: preliminary study. Geological Quarterly, 54 (4): 465-476

Peryt, T.M., Durakiewicz, T., Peryt, D., Poberezhskyy, A., 2012. Carbon and oxygen isotopic composition of the Middle Miocene Badenian gypsum-associated limestones of West Ukraine. Geologica Acta, 10: 319-332.

Petrichenko, O.I., 1973. Metody doslidzhennya vkluchen u mineralakh galogennykh porid (in Ukrainian). Naukova Dumka, Kiev. Methods of study of inclusions on minerals of saline deposits. In: Fluid Inclusion Res. Proc. COFFI (ed. E. Roedder), 1979, 12: 214-274. University of Michigan Press, Ann Arbor.

Petrichenko, O.I., 1988. Fiziko-khimicheskiye usloviya osadkoobrazovaniya v drevnikh solerodnykh basseynakh (in Russian). Naukova Dumka, Kiev.

Petrichenko, O.I., Peryt, T.M., Poberegski, A.V., 1997. Peculiarities of gypsum sedimentation in the Middle Miocene Badenian evaporite basin of Carpathian Foredeep. Slovak Geological Magazine, 3: 91-104.

Pierre, C., 1985. Isotopic evidence for the dynamic redox cycle of dissolved sulphur compounds between free and interstitial solutions in marine salt pans. Chemical Geology, 53: 191-196.
Posokhov, Y.V., 1975. Obshchaya gidrogeokhimiya (in Russian). Nedra. Moskva

Postgate, J., 1960. The economic activities of sulphate-reducing bacteria. Progress in Industrial Microbiology, 2: 48-68.

Raab, M., Spiro, B., 1991. Sulfur isotopic variations during seawater evaporation with fractional crystallization. Chemical Geology, 86: 323-333.

Stupnitskiy, V.M., Fedchenko, A.I., Korzun, N.I., 1978. Rezultaty rekognostsirovochno-poiskovykh rabot na kaliynyye soli na ploshchadi Nezhukhov-Grinevka Lvovskoy i Ivano-Frankovskoy oblastey USSR za 1975-1978 (in Russian). Otchet o NIR (v 4-kh knigakh). Kiev.

Thode, H.G., Monster, R.J., 1965. Sulfur isotope geochemistry of petroleum, evaporites and ancient seas. AAPG Memoir, 4: 367-377.

Thode, H.G., Monster, R.J., Dunford, H.B., 1961. Sulfur isotope geochemistry. Geochimica Cosmochimica Acta, 26: 159-174.

Valyashko, M.G., 1962. Zakonomernosti formirovaniya mestorozhdeniy soley (in Russian). Moskva. Izd-vo MGU.

Valyashko, M.G., Mandrykina, T.V., 1952. Brom v solyanykh otlozheniyakh kak geneticheskiy i poiskovyy priznak (in Russian). Trudy VNIIG, 23: 54-92.

Valyashko, M.G., Pelsh, G.K., 1952. Metamorfizatsiya nasyshchennykh sulfatnykh rastvorov bikarbonatom kaltsiya (in Russian). Trudy VNIIG, 23: 177-200.

Vinogradov, A.P., Grinenko, V.A., Ustinov, V.I., 1962. Izotopnyy sostav sery $v$ otlozheniyakh Chernogo morya (in Russian). Geokhimiya, (10): 851-873.

Vul, M.Y., Denega, B.I., Krupsky, Y.Z., Nimets, M.V., Svyrydenko, V.G., Fedyshyn, V.O., 1998. Atlas of Oil and Gas Fields of Ukraine in Six Volumes (in Ukrainian with English summary). Western Oil-and-Gas-Bearing Region, 4. Vydavnictvo Evropy, Lviv.

Yaremchuk, Y.V., Galamay, A.R., 2009. Mineral composition of water-insoluble residue of the Badenian rock salt from Ukrainian Fore-Carpathian (Hrynivka area) (in Ukrainian with English summary). Geologiya i Geokhimiya Horyuchykh Kopalyn, (1): 79-90.

Yeremenko, N.A., Pankina, R.G., 1971. Variations of sulphate of modern and ancient marine waters of the Soviet Union (in Russian with English summary). Geokhimiya, (1): 81-91. 